\title{
Cronobacter sakazakii local isolates response to acid stress and their resuscitability
}

\author{
${ }^{1}$ Hati, R.P., ${ }^{1,2 *}$ Dewanti-Hariyadi, R. and ${ }^{1,2}$ Nuraida, L. \\ ${ }^{1}$ Department of Food Science and Technology, Faculty of Agricultural Technology, IPB University (Bogor \\ Agricultural University), IPB Dramaga, Bogor 16680, Indonesia \\ ${ }^{2}$ Southeast Asian Food and Agricultural Science and Technology Center, IPB University (Bogor \\ Agricultural University), Jl. Puspa Lingkar Kampus of IPB Dramaga, Bogor 16680, Indonesia
}

Article history:

Received: 17 July 2019

Received in revised form: 6 September 2019

Accepted: 9 September 2019

Available Online: 16

September 2019

\section{Keywords:}

Acid Stress,

Cronobacter sakazakii,

Detection methods,

Food safety,

Resuscitation,

Viable but non-culturable (VBNC)

DOI:

https://doi.org/10.26656/fr.2017.4(1).257

\begin{abstract}
Cronobacter spp. has been reported to cause meningitis, necrotizing enterocolitis, and septicemia in a group of infants through the consumption of powder infant formula. These bacteria are reported to withstand various stress conditions such as heating, drying, low water activity, low $\mathrm{pH}$, etc. A local isolate of Cronobacter sakazakii YRt2a was reportedly survived and entered Viable But Non-Culturable (VBNC) conditions during desiccation stress. This study aims to study the behavior of local isolates of Cronobacter spp. in response to acid stress and its resuscitability. C. sakazakii E2 and YRt2a were grown in TSB at $\mathrm{pH} 3.0 \pm 0.2$ or $3.5 \pm 0.2$. The number of culturable cells and viable cells were enumerated by the Total Plate Count and Direct Viable Count methods, respectively. Resuscitation was done by growing the stress or VBNC cells in TSB with or without sodium pyruvate, catalase, Tween 20, or Cronobacter autoinducer. The results showed that $C$. sakazakii E2 and YRt2a entered VBNC state after 60 mins of exposure to $\mathrm{pH}$ $3.0 \pm 0.2$, while remained culturable after 120 minutes exposure to $\mathrm{pH} 3.5 \pm 0.2$. TSB with or without sodium pyruvate, catalase, Tween 20, or Cronobacter autoinducer could resuscitate the stress or VBNC cells of $C$. sakazakii. Stress or VBNC state experienced by C. sakazakii in response to acid tends to be transient and can be resuscitated. C. sakazakii experiencing stress or VBNC may pose a risk for food safety.
\end{abstract}

\section{Introduction}

Cronobacter spp. is able to cause meningitis, necrotizing enteritis, and septicemia in certain of infants through the consumption of powder infant formula. These pathogenic bacteria are reported to be resistant to various stresses such as heating (Arroyo et al., 2009; Dancer et al., 2009), drying (Breeuwer et al., 2003; Dancer et al., 2009), low water activity (Dancer et al., 2009) and low pH (Dancer et al., 2009). These bacteria grow rapidly at $\mathrm{pH} 5.0$, the range of gastric $\mathrm{pH}$ for newborns and infants (Álvarez-Ordóñez et al., 2014) and have a minimum $\mathrm{pH}$ for growth at $\mathrm{pH} 3.9$ (Dancer et al., 2009). These bacteria were also reported to experience slow growth at $\mathrm{pH} 3.5$, rapidly lose viability at $\mathrm{pH} 3.0$ (Edelson-Mammel et al., 2006), and do not survive at $\mathrm{pH}$ 2.5 (Fakruddin et al., 2014).

Foodborne pathogenic bacteria respond to stress inside and outside various hosts (Rychlik and Barrow, 2005; Begley and Hill 2015). Cronobacter sakazakii responded to stress during contact with the surface of food equipment made of copper alloys (Elguindi et al., 2012) or during biofilm formation on stainless steel surfaces (Sinaga et al., 2016). Food processing such as drying different atmospheric relative humidities (Lang et al., 2017), oven drying (Musa et al., 2017), freeze-drying and spray-drying (Wan-Ling et al., 2010) can cause bacteria to experience stress. Similarly, exposure to Clidox-S and Quatricide disinfectants (Li et al., 2013), desiccation (Elguindi et al., 2012; Jameelah et al., 2018) and acidification (Edelson-Mammel et al., 2006) also cause stress. Exposure of foodborne pathogenic bacteria to stress conditions causes low transcription activity, increased ribosomal RNA degradation, and non-coding RNA regulation (Deng et al., 2012), reduced cytoplasmic membranes fluidity (Yang et al. 2014), slow enzymatic reactions and metabolic rate decline (Maserati et al., 2017).

Yousef and Courtney (2003) describe the stresses faced by foodborne microorganisms vary during the food production process. Microorganisms can experience three stages of stress. First, mild stress that could reduce 
or restrain the growth rate and maintain culturability. Second, moderate stress, which is sublethal stress that reduces or restrains the growth rate and results in the loss of ability to be cultured. Third, extreme or severe stress which is generally lethal and results in the death of most populations. When cells are under stress, cells respond in various ways such as synthesizing protective protein, temporary increase in lethal factor resistance, cell transformation into latent conditions or Viable But NonCulturable/VBNC, avoidance of host defense mechanisms, and adaptive mutations (Yousef and Courtney, 2003).

Stress conditions in bacteria can induce cells to enter the VBNC state, i.e. bacteria can no longer be cultured on conventional culture media but still have viability (Ramamurthy et al., 2014). Foodborne pathogens in VBNC state can pose a risk if they continue to be undetected by the standard laboratory tests applied (Highmore et al., 2018). Some bacteria experiencing VBNC can be resuscitated inappropriate conditions so that they restore the cells initial state and can be metabolically active again (Oliver, 2005; Oliver, 2010; Pinto et al., 2011; Pinto et al., 2015). Resuscitation can be done with media such as the autoinducer supernatant (Pinto et al., 2011), a medium containing catalase (Na et al., 2006; Zeng et al., 2013; Imamura et al., 2015), Tween 20 (Zeng et al., 2013), pyruvate and LuriaBertani medium ( $\mathrm{Na}$ et al., 2006).

Research on Cronobacter spp. response to acid stress and whether they experience VBNC are limited. This study aims to observe the response of Cronobacter spp. to acid exposure, their ability to enter the VBNC state and to be resuscitated. Knowledge gained from research on the response to acid stress could explain why the bacteria could survive stomach acid. Study in the resuscitation of VBNC Cronobacter spp. can be used for the development of their detection methods.

\section{Material and methods}

The bacteria used in this study were $C$. sakazakii E2 isolated from follow-up formula (Estuningsih et al. 2006) and C. sakazakii YRt2a (JF800182) from powder infant formula (Dewanti-Hariyadi et al., 2010).

Materials used include Tryptic Soy Agar (TSA) (Oxoid Ltd., UK), Tryptic Soy Broth (TSB) (Oxoid Ltd., UK), Brain Heart Infusion Broth (BHIB) (Merck, Darmstadt, Germany), Brilliance Enterobacter Sakazakii Agar (BESA) (Oxoid Ltd., UK), Buffered Peptone Water (BPW) (Oxoid Ltd., UK), Phosphate Buffered Saline (PBS) 10X [700 mL distilled water; $80 \mathrm{~g}$ sodium chloride $(\mathrm{NaCl}) ; 2 \mathrm{~g}$ of potassium chloride $(\mathrm{KCl}) ; 14.4 \mathrm{~g}$ sodium phosphate (Na2HPO4); 2.4 g monopotassium phosphate $(\mathrm{KH} 2 \mathrm{PO} 4)]$, sodium pyruvate $(0.1 \% \quad \mathrm{v} / \mathrm{v})$ (100mM; Sigma-Aldrich, USA), catalase from mice liver (1\% w/v， 3500 units/mgProt.) (1200 units/mgProt; Sigma-Aldrich, USA), Tween $20(3 \%$ v/v) (Merck, Darmstadt, Germany), Cronobacter autoinducer $(50 \%$ dilution in TSB; $1: 1$ ), yeast Extract (YE) $0.025 \% \mathrm{w} / \mathrm{v}$ (Oxoid Ltd., UK), Nalidixic Acid (NA) $0.002 \% \mathrm{w} / \mathrm{v}$ (Sigma-Aldrich, USA), Acridine Orange (AO) 0.0026\% w/v (Sigma-Aldrich, USA), Gram's staining, hydrochloric acid (HCL) $10 \mathrm{~N}$, ethanol [70\%] and distilled water.

The instruments used include glass or stainless steel microbiology laboratories equipment and general analysis for microbiological laboratories equipment, analytical balance, centrifugation tubes, centrifugation (Hermle Labortechnik, Wehningen, Germany), filter (pore filter size $0.22 \mu \mathrm{m}$ ), $\mathrm{pH}$ meter (Eutech $\mathrm{pH} 700$, Eutech Instruments Pte Ltd., Singapore), sterile stainless steel chips $1 \times 1 \mathrm{~cm}$ (SSC) affixed to the microscope slide, light microscopes (Olympus, Olympus Corporation, USA), and fluorescent microscopes (Olympus, Olympus Corporation, USA).

\subsection{Acid stress induction and evaluation of cell culture and viability}

A total of $0.1 \mathrm{~mL}$ of 18 -hour culture of $C$. sakazakii was inoculated into $10 \mathrm{~mL}$ TSB media added with $10 \mathrm{~N}$ $\mathrm{HCl}$ such that it had a $\mathrm{pH}$ of $3.0 \pm 0.2$ or $\mathrm{pH} 3.5 \pm 0.2$ (Edelson-Mammel et al. 2006) and the initial number of the bacteria was ca. $\pm 10^{6} \mathrm{CFU} / \mathrm{mL}$. Similarity, the same amount of was inoculated into TSB with $\mathrm{pH} 7.0 \pm 0.2$ as a control. After incubation at room temperature for 0,5 , $15,30,45,60,75,90,105$, and 120 mins samples were taken and the number of culturable cells was enumerated by the total plate count (TPC) method (BAM 2001). The number of colonies was transformed into log values $(\mathrm{CFU} / \mathrm{mL})$.

The number of viable cells was calculated by incubating the above samples in mixtures of YE and NA for $18 \mathrm{hrs}$ under dark conditions. A total of $0.05 \mathrm{~mL}$ of the sample suspension was pipetted onto the SSC, AO was added and incubated at room temperature in dark conditions for 5 mins. The SSC was then rinsed with sterile PBS and air-dried. The SSC was observed under a fluorescence microscope at a wavelength of $395 \mathrm{~nm}$ and emissions of $509 \mathrm{~nm}$. The viable cells were enumerated in ten fields as the cells that fluoresce green light and the results were expressed into Log cells/mL (modification Sinaga et al., 2016). The light green fluorescence cells were obtained when AO dyes bind to dsDNA (Neeraja et al., 2017). Stress condition is defined when there is a difference between the number of culturable cells and viable cells. Meanwhile, VBNC is defined when there 
are no culturable cells on agar media but there are still viable cells as observed under the fluorescence microscope.

\subsection{Resuscitation of stressed or VBNC C. sakazakii}

Resuscitation of $C$. sakazakii E2 and YRt2a experiencing stress or VBNC state was carried out in TSB medium, TSB with Sodium pyruvate $(0.1 \% \mathrm{v} / \mathrm{v})$ (Sinaga et al., 2016), TSB with Catalase from mice liver $(1 \% \mathrm{w} / \mathrm{v})$ (Zeng et al., 2013 with modification) or TSB with Tween $20(3 \% \mathrm{v} / \mathrm{v})$ (Zeng et al., 2013 with modification) as well as in TSB containing Cronobacter autoinducer using most probable number (MPN) approach (Pinto et al., 2011 with modification).

For resuscitation in TSB containing sodium pyruvate, catalase or Tween 20 , as much as $0.1 \mathrm{~mL}$ of stress or VBNC C. sakazakii was added into $10 \mathrm{~mL}$ of resuscitation media and incubated at $37^{\circ} \mathrm{C}$ for $24 \mathrm{hrs}$. After incubation, $0.1 \mathrm{~mL}$ of the suspension was serially diluted and plated on TSA and incubated $37^{\circ} \mathrm{C}$ for $24-48$ hrs. Enumeration of bacteria after resuscitation in TSB, TSB with sodium pyruvate, TSB with Catalase, TSB with Tween 20 were conducted as above.

Resuscitation in media containing autoinducer was done by the MPN method (BAM 2010). Cronobacter autoinducer was made by growing $C$. sakazakii $\mathrm{E} 2$ or $C$. sakazakii YRt2a for $18 \mathrm{hrs}$ in TSB. The culture obtained was centrifuged $\left(1789 \times \mathrm{g}, 4^{\circ} \mathrm{C}, 30 \mathrm{mins}\right)$ and the autoinducer was obtained by filtering the supernatant through a $0.22 \mu \mathrm{m}$ filter. As much as $0.5 \mathrm{~mL}$ suspension of stressed or VBNC cells was added into $4.5 \mathrm{~mL}$ of TSB containing Cronobacter autoinducer (1:1) and incubated at $37^{\circ} \mathrm{C}$ for $24 \mathrm{hrs}$. A set of control was also made in TSB. Enumeration of $C$. sakazakii after resuscitation was made using MPN Table (BAM 2010).

\section{Results}

3.1 Acid stress induction and evaluation of culturable and viable cells

The response of $C$. sakazakii $\mathrm{E} 2$ to acid exposure is presented in Figures 1 and 2, while the response of $C$. sakazakii YRt2a to acid exposure is presented in Figures 3 and 4. Exposure to low $\mathrm{pH}$ inhibits the growth of $C$. sakazakii E2 and YRt2a as seen from the decrease in the number of culturable cells. As a control, the number of C. sakazakii grown at $\mathrm{pH} 7.0$ increased to $7.69 \log$ for $\mathrm{E} 2$ and 7.20 log for YRt2a after 2 hours of incubation.

C. sakazakii E2 (Figure 1) entered stress condition after 30 mins of exposure to $\mathrm{pH}$ 3.0, while, C. sakazakii YRt2a (Figure 3) entered stress condition after 15 mins of exposure to $\mathrm{pH}$ 3.0. The stress condition was shown by the difference in the number of colonies of $C$. sakazakii and the number of the viable cells. At $\mathrm{pH} 3.0$, both isolates reached below the detection limit (1.4 log $\mathrm{CFU} / \mathrm{mL}$ or $<2.5 \times 10^{1} \mathrm{CFU} / \mathrm{mL}$ ) before $60 \mathrm{mins}$ of incubation. E2 isolate can no longer be cultured $(<1$ $\mathrm{CFU} / \mathrm{mL}$ ) after 60 mins while YRt2a isolate became unculturable at 120 mins. During the incubation period, the number of viable cells for both isolates were always higher than those of culturable cells (TPC) (Figure 1 and 3). After exposure to $\mathrm{pH} 3.0$ for 60 mins, C. sakazakii E2 entered VBNC while $C$. sakazakii YRt2a reached VBNC after in the 120 minutes exposure to acid stress condition.

At pH 3.5, both C. sakazakii E2 and YRt2a began to experience stress after 30 mins (Figures 2 and 4). $C$. sakazakii E2 and YRt2a grown at $\mathrm{pH} 3.5$ decreased more slowly than those at $\mathrm{pH}$ 3.0. Both isolates also remained culturable up to $2 \mathrm{hrs}$ incubation, although the number of bacteria was lower than the detection limit. The viable cells as seen by the microscope also showed higher count, suggesting that the bacteria experienced stress. These results suggested that at $\mathrm{pH} 3.5$, C. sakazakii E2 or YRt2a never entered VBNC state.

\subsection{Resuscitation of stressed or VBNC C. sakazakii}

C. sakazakii E2 and YRt2a either under stress or VBNC can be resuscitated in various resuscitation media. The resuscitation results of E2 and YRt2a isolates with TSB only and with TSB supplemented with sodium pyruvate, catalase and Tween 20 are presented in Table 1. TSB only can resuscitate the acid stress and VBNC cells as seen by the number of post-resuscitation cells that reach up to the 5-6 log. Cells resuscitated in TSB media supplemented with sodium pyruvate, catalase and Tween 20 had a 1-2 log higher cell number than those

Table 1. The response of stress and VBNC Cronobacter spp. in various resuscitation media

\begin{tabular}{|c|c|c|c|c|c|c|c|}
\hline \multirow{3}{*}{ Isolates } & \multirow{3}{*}{ Cells State } & \multirow{3}{*}{$\mathrm{pH}$ value } & \multirow{3}{*}{$\begin{array}{l}\text { Time of exposure } \\
\text { to acid (Minutes) }\end{array}$} & \multicolumn{4}{|c|}{ Number of bacteria post-resuscitation in the media } \\
\hline & & & & \multicolumn{4}{|c|}{ Log Cells/mL } \\
\hline & & & & TSB & $\begin{array}{l}\text { TSB + Sodium } \\
\text { Pyruvate }\end{array}$ & TSB + Catalase & TSB + Tween 20 \\
\hline E2 & VBNC & 3 & 60 & 6.68 & $8.09 *$ & $8.02 *$ & $8.20^{*}$ \\
\hline YRt2a & VBNC & 3 & 120 & 5.93 & $7.62 *$ & $8.17 *$ & $8.21 *$ \\
\hline E2 & Stress & 3.5 & 120 & 5.99 & $7.72 *$ & $8.04 *$ & $8.13 *$ \\
\hline YRt2a & Stress & 3.5 & 120 & 6.06 & $8.09 *$ & $8.17 *$ & $8.13 *$ \\
\hline
\end{tabular}

$*$ Number of bacteria $>2.5 \times 10^{7}$ Cells $/ \mathrm{mL}$ 


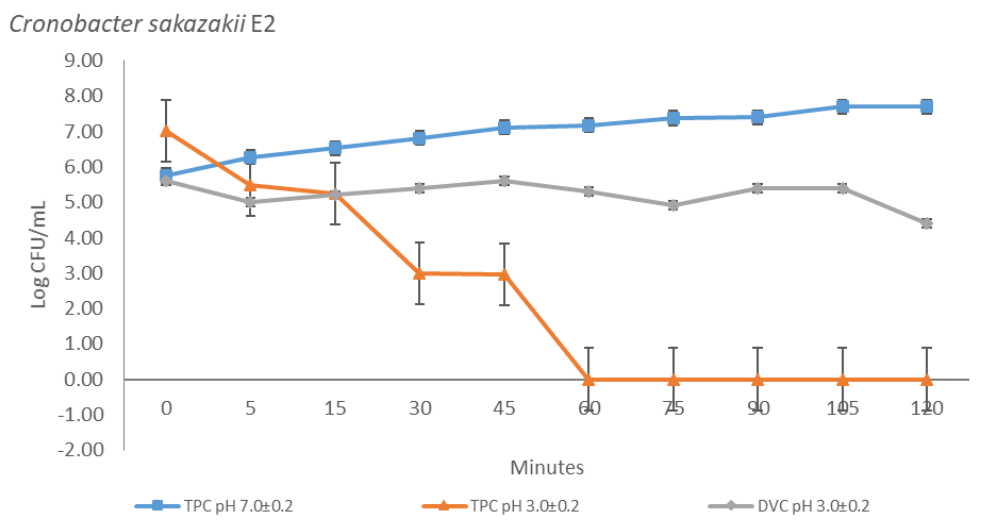

Figure 1. The fate of $C$. sakazakii E2 in response to acid exposure $\mathrm{pH} 3.0$ and its control $\mathrm{pH}$ 7.0. (The abbreviations are

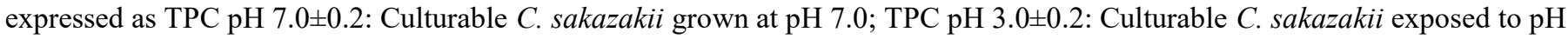
3.0; DVC pH 3.0 \pm 0.2 : Viable C. sakazakii exposed to $\mathrm{pH} 3.0$ )

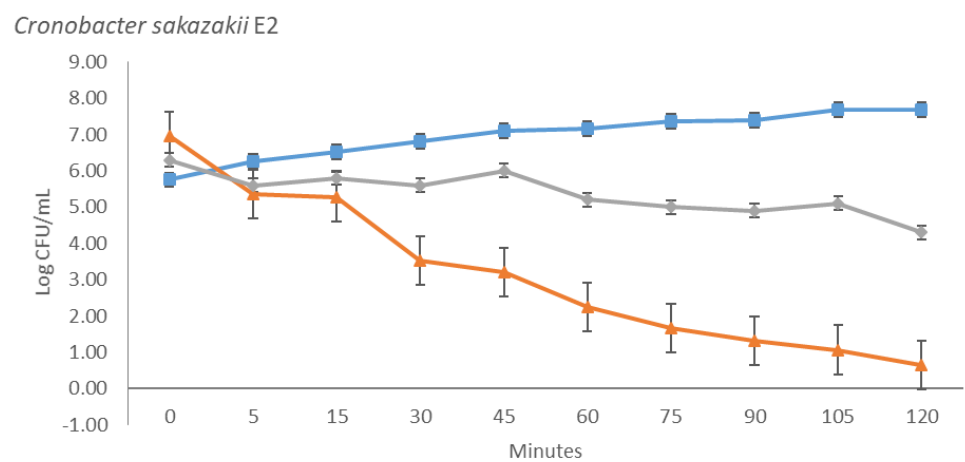

$=-\mathrm{TPCPH} 7.0 \pm 0.2$

$-\mathrm{TPC}$ PH $3.5 \pm 0.2$

$\rightarrow \mathrm{DVCpH} 3.5 \pm 0.2$

Figure 2. The fate of $C$. sakazakii E2 in response to acid exposure $\mathrm{pH} 3.5$ and its control pH 7.0. (The abbreviations are

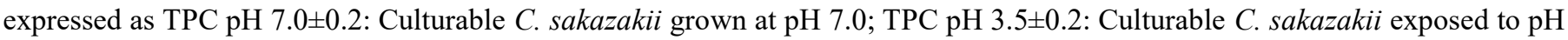
3.5; DVC pH 3.5 \pm 0.2 : Viable C. sakazakii exposed to $\mathrm{pH} 3.5$ )

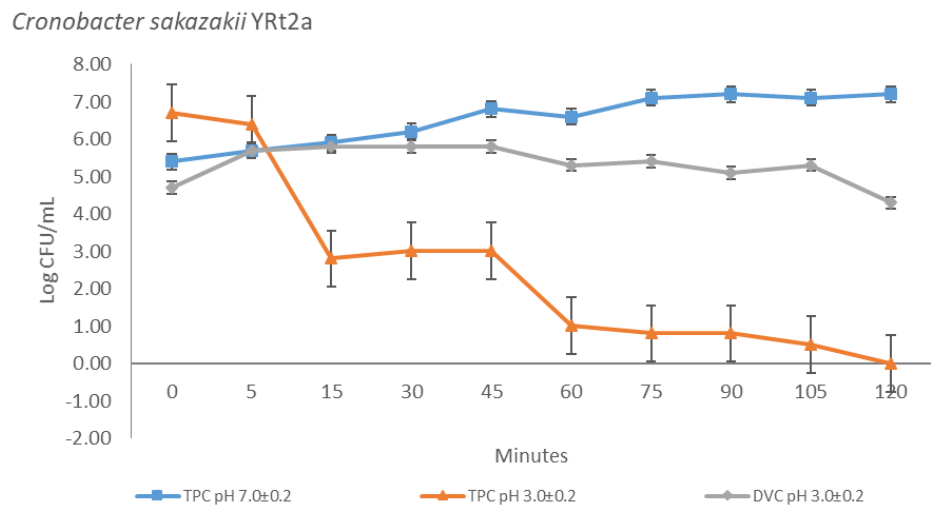

Figure 3. The fate of $C$. sakazakii YRt2a in response to acid exposure $\mathrm{pH} 3.0$ and its control $\mathrm{pH}$ 7.0. (The abbreviations are

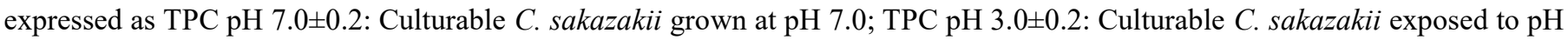
3.0; DVC pH 3.0 \pm 0.2 : Viable C. sakazakii exposed to $\mathrm{pH} 3.0$ )

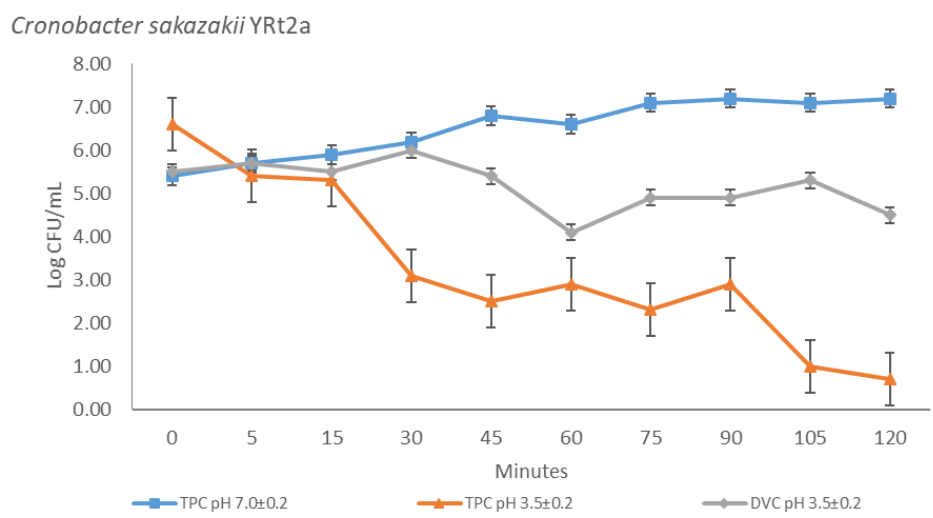

Figure 4. The fate of $C$. sakazakii YRt2a in response to acid exposure $\mathrm{pH} 3.5$ and its control pH 7.0. (The abbreviations are

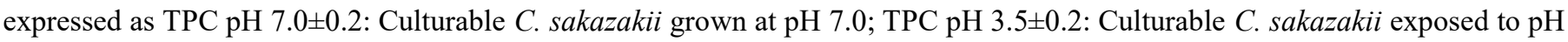
3.5; DVC pH 3.5 \pm 0.2 : Viable C. sakazakii exposed to $\mathrm{pH} 3.5$ ) 
Table 2. Response of stress and VBNC Cronobacter spp. in media containing autoinducer

\begin{tabular}{|c|c|c|c|c|c|}
\hline \multirow{3}{*}{ Isolate } & \multirow{3}{*}{ Cells State } & \multirow{3}{*}{$\mathrm{pH}$ value } & \multirow{3}{*}{$\begin{array}{l}\text { Time of exposure to } \\
\text { acid (Minutes) }\end{array}$} & \multicolumn{2}{|c|}{ Number of bacteria post-resuscitation in the } \\
\hline & & & & \multicolumn{2}{|r|}{$\log \mathrm{MPN} / \mathrm{mL}$} \\
\hline & & & & TSB & TSB + Cronobacter autoinducer \\
\hline E2 & VBNC & 3 & 60 & 4.38 & $5.04^{* *}$ \\
\hline YRt2a & VBNC & 3 & 120 & 3.29 & $5.04 * *$ \\
\hline E2 & Stress & 3.5 & 120 & 3.34 & $5.04 * *$ \\
\hline YRt2a & Stress & 3.5 & 120 & 3.41 & $5.04 * *$ \\
\hline
\end{tabular}

**Number of bacteria $>1.1 \times 10^{5} \mathrm{MPN} / \mathrm{mL}$

resuscitated in TSB alone. Resuscitation using TSB media supplemented with Cronobacter autoinducer (Table 2) also resulted in $1 \log$ higher number than that of the control.

\section{Discussion}

\subsection{Acid stress induction and evaluation of cell culture} and viability

The results suggested that $C$. sakazakii $\mathrm{E} 2$ and YRt2a exposed to acid for up to 120 mins experienced stress and capable of entering the VBNC state. Both isolates showed sensitivity to acid exposure and rapidly decreased in the number of culturable cells. Wesche et al. (2009) stated that acid stress can occur in low $\mathrm{pH}$ conditions when $\mathrm{H}^{+}$ions cross bacterial membrane cells and acidify the cytoplasm. Loss of cation from a key metabolic could occur due to exposure to a low $\mathrm{pH}$ environment, e.g. the loss of Magnesium which is an integral part of ribosome integrity. Shifts in $\mathrm{pH}$ can also interfere with the proton motive force and change the protein profile of the outer membrane in Gram-negative cells. This can cause cells to fail to use proton pumps to remove $\mathrm{H}^{+}$ions from the cells (Pienaar et al., 2019). Acidification also disrupts key biochemical processes (Chung et al., 2006). After exposure to acidic conditions, there is an increase in the expression of defense enzymes to help maintain homeostatic $\mathrm{pH}$ in cells (Flint et al., 2016).

Oliver (2010) suggested that entering VBNC is a strategy of bacterial survival when environmental conditions are not suitable for normal growth. Although VBNC cells cannot be cultured, they can maintain metabolic activity and express toxic proteins (Ding et al., 2017), energy activity and respiratory activity (Pienaar $e t$ al., 2019), membrane integrity (Lahtinen et al., 2008), and main regulatory gene from the general stress response (Kusumoto et al., 2012). Pinto et al. (2013) explained that cell populations that can be cultured when induced into VBNC conditions will experience a reduction in the number of cells that can be cultured to below the detection limit and other cell populations i.e. injury cells, VBNC cells, and dead cells will increase. Wei and Zhao (2018) revealed that the ability and speed of induction of the VBNC state were mainly related to incubation conditions and cells and species of cells.

The VBNC cells of E2 and YRt2a isolates still showed metabolic activity because the number of viable cells was always higher than the culturable cells. The DVC method is a fluorescent staining test to determine cell viability and membrane integrity (Schottroff et al., 2018). The fluorescence dye used in this study was acridine orange, a fluorochrome and cationic dye (Neeraja et al., 2017). Acridine orange emits green fluorescence light when bound to dsDNA (at $520 \mathrm{~nm}$ ) and reddish fluorescence light when bound to ssDNA or RNA (at $650 \mathrm{~nm}$ ) (Neeraja et al., 2017). This allows differentiation between viable cells and dead cells. Cells that grow actively or reproduce will glow green. In the meantime, slow or non-reproductive cells will appear orange (Fakruddin et al., 2013).

In this study, acid exposure was carried out in TSB media adjusted by $\mathrm{HCl}$. Marieb and Hoehn (2013) explained that $\mathrm{HCl}$ as a strong inorganic acid will completely dissociate into protons and chloride ions. Beales (2004) explains that increasing acidity conditions will have an impact on the disruption of cellular component synthesis and induce cell death as a result of damage to the outer membrane, disruption of $\mathrm{pH}$ homeostasis, DNA and enzymes.

The results showed that a decrease in the number of C. sakazakii E2 and C. sakazakii YRt2a due to acid was faster when compared to those reported by several other researchers. Edelson-Mammel et al. (2006) showed that Enterobacter sakazakii (4.01C, 607, ATCC 29544, ATCC 51329, NQ1-Environ, NQ2-Environ, Environ NQ3, LCDC648, LCDC648, LCDC 674, CDC A3 (10), SK90, EWFAKRC11NNV1493) experienced a decrease in cells after $5 \mathrm{hrs}$ of exposure to $\mathrm{pH} 3.0$ and 3.5. Fu et al. (2011) also found that Cronobacter NC041, NC1006, and NC830 could not survive at $\mathrm{pH} 3.0$ and $3.5(\mathrm{pH}$ value $<4.0$ ) to $24 \mathrm{hrs}$ of incubation. Additionally, Hsiao et al. (2010) reported that C. sakazakii BCRC 13988 after $3 \mathrm{hrs}$ of exposure to gastric acid simulations $(\mathrm{pH}$ 3.0) was more rapidly decreasing than that exposed to $\mathrm{pH}$ 3.5. Our results suggested both isolates, $C$. sakazakii E2, and C. sakazakii YRt2a possibly are more 
sensitive to acid than the above-reported isolates. The sensitivity of $C$. sakazakii to acid is reported to be varied and strain- as well as acid-dependent (AlvarezOrdóñez et al., 2012; Zhu et al., 2013).

C. sakazakii E2 entered VBNC state at 60 mins while YRt2a isolate entered at 120 mins of exposure to $\mathrm{pH}$ 3.0. The two isolates did not enter the VBNC state during exposure to $\mathrm{pH} 3.5$ for 120 mins. There have been no previous reports suggesting Cronobacter spp. enter VBNC because of acid stress. However, some have reported that Cronobacter spp. enter VBNC state because of other stress. Jameelah et al. (2018) reported that $C$. sakazakii YRt2a entered the VBNC state after 24 days of exposure to desiccation conditions. Sinaga et al. (2016) also reported that during the formation of biofilms YRt2a isolate entered VBNC state on the $63^{\text {rd }}$ day. Moreover, Fakruddin et al. (2017) suggested that nutritional deficiencies and low temperatures experience can induce $C$. sakazakii to enter the VBNC state after 40 days of incubation.

The results also showed that local isolates of $C$. sakazakii E2 entered the VBNC faster than $C$. sakazakii YRt2a. This difference in response is thought to be due to the differences in the characteristic of the two isolates. E2 isolate was obtained from a follow-up formula (Estuningsih et al., 2006) while YRt2a isolate was isolated from powder infant formula (Dewanti-Hariyadi et al., 2010). Previous research stated that $\mathrm{E} 2$ isolate was more toxic (Nurjanah et al., 2013) and able to survive longer during oven drying (Musa et al., 2017) as compared to other local isolates of $C$. sakazakii. Pinto et al. (2011) stated that the ability of bacteria to enter the VBNC depends on the strain.

\subsection{Resuscitation of stressed or VBNC C. sakazakii}

The results show that both stress and VBNC cells of C. sakazakii can be revived in the resuscitation media used. Implies that both isolates may experience mild stress or sublethal injury. Li et al. (2014) in his review stated that resuscitation can be triggered by various stimulants e.g. increased temperature, nutrient concentration and the presence of local C. sakazakii E2 dan YRt2a host cells. Resuscitation process can be mediated by physical stimulants and various types of chemical stimulants. Another trigger for resuscitation is the presence of specific components acting as signals, e.g. amino acids, trigger-resuscitation factors (Rpf) and autoinducers. Pinto et al. (2011) stated that factors influencing the success of resuscitation are the strains, conditions that induce VBNC, age of VBNC cells, conditions of resuscitation media, and conditions that induce resuscitation. Based on that idea, the resuscitation process that occurs in stress cells and VBNC of $C$. sakazakii E2 and C. sakazakii YRt2a may be triggered by the existing stimulants in resuscitation media.

Our result implied that E2 and YRt2a isolate experience stress due to acidification in the cytoplasm because the cells gain culturability when they are removed into a neutral and rich environment such as TSB. TSB medium may act not only as a physical stimulant but also as a source of nutrients and energy to sustain homeostasis $\mathrm{pH}$ in the stressed or VBNC cells. Dancer et al. (2009) revealed that TSB has amino acids (glutamate, lysine, decarboxylase) that could increase cytoplasmic $\mathrm{pH}$. The results on both isolates are inaccord with Pienaar et al. (2019) who revealed that neutral media can be used for bacterial proliferation and recovery. In addition, Joshi et al. (2014) reported that nutrient-rich media such as TSB can recover C. sakazakii 29004 and 29544.

Beside physical stimulants, the presence of chemical stimulants i.e. sodium pyruvate, catalase and Tween 20 could play a role in the resuscitation of $C$. sakazakii stress and VBNC. Based on the results of the study, TSB supplemented with sodium pyruvate and catalase could increase the number of post-resuscitation cells E2 and YRt2a isolates. These imply that both isolates possibly accumulate hydrogen peroxide $\left(\mathrm{H}_{2} \mathrm{O}_{2}\right)$ during stress. Oliver (2010) stated $\mathrm{H}_{2} \mathrm{O}_{2}$ is one factor that causes bacteria to enter VBNC. Kawasaki and Kamagata (2017) claimed that the presence of $\mathrm{H}_{2} \mathrm{O}_{2}$ binding agents e.g. catalase and sodium pyruvate is known to effectively degrade $\mathrm{H}_{2} \mathrm{O}_{2}$. Both of these compounds bind $\mathrm{H}_{2} \mathrm{O}_{2}$ in the media. Subsequently, sodium pyruvate reacts with $\mathrm{H}_{2} \mathrm{O}_{2}$ to produce acetic acid, $\mathrm{CO}_{2}$ and $\mathrm{H}_{2} \mathrm{O}_{2}$. Meanwhile, catalase converts $\mathrm{H}_{2} \mathrm{O}_{2}$ to $\mathrm{O}_{2}$ and $\mathrm{H}_{2} \mathrm{O}$ through its enzymatic activity. Al-Holy et al. (2008) reported that the addition of sodium pyruvate $(0.1 \%)$ could recover Enterobacter sakazakii cells (ATCC 12868, ATCC 29004, FSM 292, FSM 287) experiencing acid stress. Morishige et al. (2013) explained the addition of pyruvate triggers macromolecular biosynthesis activities such as DNA synthesis, protein synthesis, activating certain metabolic pathways for energy metabolism including the reduction of respiratory activity on CTC until the VBNC cell population regains the ability to be cultured. Fakruddin et al. (2017) have reported that VBNC Cronobacter sakazakii cells can be resuscitated by the addition of catalase. Catalase degrades the accumulated of $\mathrm{H}_{2} \mathrm{O}_{2}$ in the cells (both externally and internally), thus increasing the cells' ability to be cultured. This study indicates that C. sakazakii E2 and YRt2a could be revived by catalase, therefore very likely the bacteria produce $\mathrm{H}_{2} \mathrm{O}_{2}$ during stress. Tween 20 is another chemical stimulant that works for the resuscitation of stress and VBNC cells of E2 and YRt2a 
isolates. Peres et al. (2011) stated that Tween 20 is a carbon source. During stress, E2 and YRt2a isolates may experience deficiencies in carbon sources, thus Tween 20 was then used by both isolates as carbon sources to increase nutrient absorption and energy metabolism. The availability of energy sources can improve the colony formation thus the ability to be cultured. Addition of Tween 20 (3\%) has been reported to resuscitate VBNC cells of Escherichia coli O157: H7 (Afari and Hung 2018) and Salmonella enterica serovar Typhi (Zeng et al., 2013).

We also found that Cronobacter autoinducer can resuscitate stress and VBNC cells of $C$. sakazakii. The results suggested that there were signals in Cronobacter autoinducer compounds that help stimulate recovery. Research conducted by Weichart and Kell (2001) revealed that $E$. coli supernatant triggered or facilitated cell division during recovery, accelerated subsequent recovery and growth. The active components in the supernatant were dialysable, heat-stable, acid-stable, alkali-stable, proteinase-stable, small, non-protein and non-ionic organic molecules. Our result was similar to Pinto et al. (2011) who reported that autoinducer obtained from the culture supernatant of $E$. coli could resuscitate $E$. coli. The supernatant is a heat-stable enterobacterial autoinducer that was used to resuscitate VBNC cells of $E$. coli.

Overall, the local isolates $C$. sakazakii E2 and YRt2a experiencing stress or VBNC could be resuscitated and gain culturability. This can be seen from the formation of colonies after treatment in resuscitation media such as TSB, TSB with sodium pyruvate, TSB with catalase, TSB with tween 20 or TSB with Cronobacter autoinducer. The ability of both isolates to be resuscitated provides an opportunity to develop enrichment media for the detection methods of the bacteria, especially Cronobacter spp. that experience acid stress such as those in acid foods.

\section{Conclusion}

Local isolates $C$. sakazakii E2 and YRt2a experienced stress and entered VBNC state when exposed to $\mathrm{pH}$ 3.0. Likewise, acid-induced stress also occurred at ph 3.5 but the bacteria remained culturable. E2 isolate decreased faster during the period of acid exposure and showed more sensitivity to acid as compared to YRt2a isolate. Furthermore, Placing stressed and VBNC cells of C. sakazakii E2 and YRt2a in TSB at $\mathrm{pH} 7.0$ was able to resuscitate the bacteria. Addition of chemical stimulants such as sodium pyruvate, catalase or tween 20 and the presence of specific components Cronobacter autoinduction further resuscitated and increase the culturability of C. sakazakii stress and VBNC. The ability of both isolates that can survive in low $\mathrm{pH}$ conditions and can be resuscitated increases the risk of food safety. Further research is needed to determine the effects and mechanisms of acid exposure on the expression of regulators, virulence, stress, VBNC and resuscitation genes.

\section{Conflict of Interest}

The authors declare no conflict of interest.

\section{Acknowledgment}

The research work was funded by the Ministry of Research, Technology and The Higher Education Republic of Indonesia through the competence-based research scheme.

\section{References}

Afari, G.K. and Hung, Y.C. (2018). Detection and Verification of the Viable but Nonculturable (VBNC) State of Escherichia coli O157: H7 and Listeria monocytogenes Using Flow Cytometry and Standard Plating. Journal of Food Science, 83(7), 1913-1920. https://doi.org/10.1111/17503841.14203

Al-Holy, M.A., Lin, M., Al-Qadiri, H.M. and Rasco, B.A. (2008). A comparative study between overlay method and selective-differential media for recovery of stressed Enterobacter sakazakii cells from infant formula. Food Microbiology, 25(1), 22-28. https:// doi.org/10.1016/j.fm.2007.09.002

Álvarez-Ordóñez, A., Cummins, C., Deasy, T., Clifford, T., Begley, M. and Hill, C. (2014). Acid stress management by Cronobacter sakazakii. International Journal of Food Microbiology, 178, 21 -28 . https://doi.org/10.1016/

j.ijfoodmicro.2014.03.001

Alvarez-Ordóñez, A., Begley, M. and Hill, C. (2012). Polymorphisms in rpoS and stress tolerance heterogeneity in natural isolates of Cronobacter sakazakii. Applied and Environmental Microbiology, 78(11), 3975-3984. https:// doi.org/10.1128/AEM.07835-11.

Arroyo, C., Condón, S. and Pagán R. (2009). Thermobacteriological characterization of Enterobacter sakazakii. International Journal of Food Microbiology, 136, 110-118. https:// doi.org/10.1016/j.ijfoodmicro.2009.09.013

Bacteriological Analytical Manual (BAM). (2001). BAM Chapter 3: Aerobic Plate Count. Retrieved on December 18, 2017 from Website Food and Drug 
Administration (FDA) https://www.fda.gov/Food/ FoodScienceResearch/LaboratoryMethods/ ucm063346.htm

Bacteriological Analytical Manual (BAM). (2010). BAM Appendix 2: Most Probable Number from Serial Dilutions Retrieved on December 18, 2017 from Website Food and Drug Administration (FDA) https://www.fda.gov/Food/FoodScienceResearch/ LaboratoryMethods/ucm109656.htm

Beales, N. (2004). Adaptation of Microorganisms to Cold Temperatures, Weak Acid Preservatives, Low $\mathrm{pH}$, and Osmotic Stress: A Review. Comprehensive Reviews in Food Science and Food Safety, 3(1), 120. https://doi.org/10.1111/j.15414337.2004.tb00057.x

Begley, M. and Hill, C. (2015). Stress Adaptation in Foodborne Pathogens. Annual Review of Food Science and Technology, 6(1), 191-210. https:// doi.org/10.1146/annurev-food-030713-092350

Breeuwer, P., Lardeau, A., Peterz, M. and Joosten, H.M. (2003). Desiccation and heat tolerance of Enterobacter sakazakii. Journal of Applied Microbiology, 95(5), 967-973. https:// doi.org/10.1046/j.1365-2672.2003.02067.x

Chung, H., Bang, W. and Drake, M. (2006), Stress Response of Escherichia coli. Comprehensive Reviews in Food Science and Food Safety, 5, 52-64. https://doi.org/10.1111/j.1541-4337.2006.00002.x

Dancer, G.I., Mah, J.-H., Rhee, M.-S., Hwang, I.-G. and Kang D.-H. (2009). Resistance of Enterobacter sakazakii (Cronobacter spp.) to environmental stresses. The Society for Applied Microbiology: Journal of Applied Microbiology, 107(5), 16061614. 2672.2009.04347.x

Deng, X., Li, Z. and Zhang, W. (2012). Transcriptome sequencing of Salmonella enterica serovar Enteritidis under desiccation and starvation stress in peanut oil. Food Microbiology, 30, 311-315. https:// doi.org/10.1016/j.fm.2011.11.001

Dewanti-Hariyadi, R., Gitapratiwi, D., Meutia, Y.R., Hidayat, S.H. and Nurjanah, S. (2010). Isolation of Enterobacter sakazakii (Cronobacter spp.) from powdered infant formula and other dried foods obtained from Bogor area. In Dewanti-Hariyadi, R., Nuraida, L., Gitapratiwi, D., Immaningsih, N. and Hariyadi, P. (Eds.). Current Issues and Challenges in Food Safety, December 2-3, 2019, p. 281-286. Bogor, Indonesia: Southeast Asian Food and Agricultural Science and Technology (SEAFAST) Center Bogor Agricultural University

Ding, T., Suo, Y., Xiang, Q., Zhao, X., Chen, S., Ye, X. and Liu, D. (2017). Review: Significance of Viable but Nonculturable Escherichia coli: Induction, Detection, and Control. Journal of Microbiology Biotechnology, 27(3), 417-428. https:// doi.org/10.4014/jmb.1609.09063

Edelson-Mammel, S., Porteous, M.K. and Buchanan, R.L. (2006). Acid resistance of twelve strains of Enterobacter sakazakii, and the impact of habituating the cells to an acidic environment. Institute of Food Technologists: Journal Of Food Science, 71(6), 201-207. https://doi.org/10.1111/ j.1750-3841.2006.00101.x

Elguindi, J., Alwathnani, H.A. and Rensing, C. (2012). Rapid inactivation of Cronobacter sakazakii on copper alloys following periods of desiccation stress. World Journal of Microbiology and Biotechnology, 28(4), 1837-1841. https://doi.org/10.1007/s11274011-0972-3

Estuningsih, S., Kress, C., Hassan, A., Akinden, O., Schineider, E. and Usleber, E. (2006). Enterobacteriaceae in dehydrated powdered infant formula manufactured in Indonesia and Malaysia. Journal of Food Protection, 69(12), 3013 - 3017. https://doi.org/10.4315/0362-028X-69.12.3013

Fakruddin, M., Mannan, K.S. and Andrew, S. (2013). Viable but Nonculturable Bacteria: Food Safety and Public Health Perspective. International Scholarly Research Notices (ISRN): Microbiology, 2013, 703813. https://doi.org/10.1155/2013/703813.

Fakruddin, M., Rahaman M.M., Ahmed, M.M. and Hoque, M.M. (2014). Stress tolerant virulent strains of Cronobacter sakazakii from food. Biological Research, 47(1), 63. https://doi.org/10.1186/07176287-47-63

Fakruddin, M., Rahaman, M.M., Hossain, M.N. and Ahmed, M.M. (2017). Induction and resuscitation of Cronobacter sakazakii into viable but non-culturable state at low temperature in water microcosm. Asian Journal of Biological Sciences, 10(2), 64-71. https:// doi.org/10.3923/ajbs.2017.64.71

Flint, A., Butcher, J. and Stintzi, A. (2016). Stress responses, adaptation, and virulence of bacterial pathogens during host gastrointestinal colonization. Microbiology Spectrum, 4(2), 1-18. https:// doi.org/10.1128/microbiolspec.VMBF-0007-2015

Fu, S., Gao, J., Liu, Y. and Chen, H. (2011). Isolation of Cronobacter spp. Isolates from infant formulas and their survival in the production process of infant formula. Czech Journal of Food Sciences, 29, 391399. https://doi.org/10.17221/255/2010-CJF5

Highmore, C.J., Warner, J.C., Rothwell, S.D., Wilks, S.A. and Keevil, C.W. (2018). Viable-but- 
nonculturable Listeria monocytogenes and Salmonella enterica serovar Thompson induced by chlorine stress remain infectious. mBio, 9(2), e00540 -18. https://doi.org/10.1128/mBio.00540-18

Hsiao, W.-L., Ho, W.-L. and Chou, C.-C. (2010). Sublethal heat treatment affects the tolerance of Cronobacter sakazakii BCRC 13988 to various organic acids, simulated gastric juice, and bile solution. International Journal of Food Microbiology, 144, 280-284. https://doi.org/10.1016/ j.ijfoodmicro.2010.10.006.

Imamura, D., Mizuno, T., Miyoshi, S. and Shinoda, S. (2015). Stepwise changes in viable but nonculturable Vibrio cholerae cells. Microbiology Immunology, 59, 305-310. https://doi.org/10.1111/1348-0421.12246

Jameelah, M., Dewanti-Hariyadi, R. and Nurjanah, S. (2018). Expression of rpoS, ompA and $h f q$ genes of Cronobacter sakazakii strain YRt2a during stress and viable but nonculturable state. Food Science Biotechnology, 27(3), 915-920. https:// doi.org/10.1007/s10068-018-0313-5

Kawasaki, K. and Kamagata, Y. (2017). PhosphateCatalyzed Hydrogen Peroxide Formation from Agar, Gellan, and k- Carrageenan and Recovery of Microbial Cultivability via Catalase and Pyruvate. Applied and Environmental Microbiology, 83(21), 1 -9. https://doi.org/10.1128/AEM.01366-17

Kusumoto, A., Asakura, H. and Kawamoto, K. (2012) General stress sigma factor RpoS influences time required to enter the viable but non-culturable state in Salmonella enterica. Microbiology and Immunology, 56(4), 228-237. https:// doi.org/10.1111/j.1348-0421.2012.00428.x

Lahtinen, S., Ahokoski, H., Reinikainen, J.P., Gueimonde, M., Nurmi, J., Ouwehand, A.C. and Salminen, S.J. (2008). Degradation of $16 \mathrm{~S}$ rRNA and attributes of viability of viable but nonculturable probiotic bacteria. Letters in Applied Microbiology, 46, 693-698. https://doi.org/10.1111/j.1472765X.2008.02374.x

Lang, E., Iaconelli, C., Zoz, F., Guyot, S., AlvarezMartin, P., Beney, L., Perrier-Cornet, J.-M. and Gervais, P. (2017). Drying parameters greatly affect the destruction of Cronobacter sakazakii and Salmonella Typhimurium in standard buffer and milk. Food Microbiology, 62, 82-91. https:// doi.org/10.1016/j.fm.2016.10.005

Li, P.-T., Hsiao, W.L., Yu, R.C. and Chou, C.C. (2013). Effect of heat shock on the fatty acid and protein profiles of Cronobacter sakazakii BCRC 13988 as well as its growth and survival in the presence of various carbon, nitrogen sources, and disinfectants. Food Microbiology, 36(2), 142-148. https:// doi.org/10.1016/j.fm.2013.04.018

Marieb, E.N. and Hoehn, K. (Eds.) (2013). Organization of the body: Chemistry comes alive, Human anatomy and physiology. $9^{\text {th }}$ ed., p. 39. San Francisco, USA: Pearson Education Inc.

Maserati, A., Fink, R.C., Lourenco, A., Julius, M.L. and Diez-Gonzalez, F. (2017). General response of Salmonella enterica serovar Typhimurium to desiccation: A new role for the virulence factors sopD and sseD in survival. PLoS ONE, 12(11), e0187692.

https://doi.org/10.1371/

journal.pone. 0187692

Morishige, Y., Fujimori, K. and Amano, F. (2013). Differential resuscitative effect of pyruvate and its analogues on VBNC (viable but non-culturable) Salmonella. Microbes and Environments, 28(2), 180186. https://doi.org/10.1264/jsme2.ME12174

Musa, A.M.A., Dewanti-Hariyadi, R. and Syamsir, E. (2017). Use of $p G F P u v$ to study the influence of drying on the survival of Cronobacter sakazakii in corn. International Journal of Science and Technology, 5(8), 104-111.

Na, S.H., Miyanaga, K., Unno, H. and Tanji, Y. (2006). The survival response of Escherichia coli $\mathrm{K} 12$ in a natural environment. Applied Microbiology and Biotechnology, 72, 386-392. https://doi.org/10.1007/s00253-005-0268-3

Neeraja, M., Lakshmi, V., Padmasri, C. and Padmaja, K. (2017). Utility of Acridine Orange staining for detection of bacteria from positive blood cultures. Journal of Microbiological Methods, 139, 215-217. https://doi.org/10.1016/j.mimet.2017.06.014

Nurjanah, S., Dewanti-Hariyadi, R., Estuningsih, S. and Suhartono, M.T. (2013). Cytotoxic activity of Cronobacter spp. isolated from Indonesian food. $13^{\text {th }}$ ASEAN Food Conference 2013, September 9-11, 2013. Singapore: Singapore Institute of Food Science and Technology (SIFST) and ASEANCommittee on Science and Technology (ASEANCOST) and Federation of the Institute of Food Science and Technology in ASEAN (FIFSTA).

Oliver, J.D. (2010). Recent finding on the viable but nonculturable state in pathogenic bacteria. Federation of European Microbiol Societies (FEMS): Microbiology Reviews, 34, 415-425. https:// doi.org/10.1111/j.1574-6976.2009.00200.x.

Oliver, J.D. (2005). The Viable but Nonculturable State in Bacteria. The Journal of Microbiology, 43(1), 93100.

Peres, N.T.A., Cursino-Santos, J.R., Rossi, A. and Martinez-Rossi, N.M. (2011). In vitro susceptibility to antimycotic drug undecanoic acid, a medium- 
chain fatty acid is nutrient-dependent in the dermatophyte Trichophyton rubrum. World Journal of Microbiology and Biotechnology, 27(7), 17191723. https://doi.org/10.1007/s11274-010-0613-2

Pienaar, J.A., Singh, A. and Barnard, T.G. (2019). Acidhappy: Survival and recovery of enteropathogenic Escherichia coli (EPEC) in simulated gastric fluid, Microbial Pathogenesis, 128, 396-404. https:// doi.org/10.1016/j.micpath.2019.01.022.

Pinto, D., Almeida, V., Santos, M.A. and Chambel, L. (2011). Resuscitation of Escherichia coli VBNC cells depends on a variety of environmental or chemical stimuli. Journal of Applied Microbiology, 110, 1601-1611. https://doi.org/10.1111/j.13652672.2011.05016.x

Pinto, D., Santos, M.A. and Chambel, L. (2015). Thirty years of viable but nonculturable state research: Unsolved molecular mechanisms. Critical Review Microbiology, 41(1), 61-76. https:// doi.org/10.3109/1040841X.2013.794127

Ramamurthy, T., Ghosh, A., Pazhani, G.P. and Shinoda, S. (2014). Current Perspectives on Viable but NonCulturable (VBNC) Pathogenic Bacteria. Frontiers in Public Health, 2(103). https://doi.org/10.3389/ fpubh.2014.00103

Rychlik, I. and Barrow, P.A. (2005). Salmonella stress management and its relevance to behaviour during intestinal colonisation and infection. Federation of European Microbiol Societies (FEMS): Microbiology Reviews, 29(5), 1021-1040. https:// doi.org/10.1016/j.femsre.2005.03.005

Schottroff, F., Fröhling, A., Zunabovic-Pichler, M., Krottenthaler, A., Schlüter, O. and Jäger, H. (2018) Sublethal Injury and Viable but Non-culturable (VBNC) State in Microorganisms During Preservation of Food and Biological Materials by Non-thermal Processes. Frontiers in Microbiology, 9, 2773. https://doi.org/10.3389/fmicb.2018.02773

Sinaga, Y.M.R., Dewanti-Hariyadi, R. and Suliantari. (2016). Cronobacter sakazakii enters viable but nonculturable state during biofilm formation. Jurnal Teknologi dan Industri Pangan, 27(2), 140-147. [In Bahasa Indonesia]. https://doi.org/10.6066/ jtip.2016.27.2.140.

Wan-Ling, H., Chang, C.-H. and Chou, C.-C. (2010). Heat shock effects on the viability of Cronobacter sakazakii during the dehydration, fermentation, and storage of lactic cultured milk products. Food Microbiology, 27(2), 280-285. https:// doi.org/10.1016/j.fm.2009.10.011

Wei, C. and Zhao, X. (2018) Induction of Viable but Nonculturable Escherichia coli O157: H7 by Low
Temperature and Its Resuscitation. Frontiers in Microbiology, 9, 2728. https://doi.org/10.3389/ fmicb.2018.02728

Weichart, D.H. and Kell, D.B. (2001). Characterization of an autostimulatory substance produced by Escherichia coli. Microbiology, 147(7), 1875-1885. https://doi.org/10.1099/00221287-147-7-1875

Wesche, A.M., Gurtler, J.B., Marks, B.P. and Ryser, E.T. (2009). Stress, sublethal injury, resuscitation, and virulence of bacterial foodborne pathogens. Journal of Food Protection, 72(5), 1121-1138. ISBN 5173558474. https://doi.org/10.4315/0362-028X72.5 .1121

Yang, Y., Kadim, M.I., Khoo, W.J., Zheng, Q., Setyawati, M.I., Shin, Y.-J., Lee, S.-C. and Yuk, H.G. (2014). Membrane lipid composition and stress/ virulence related gene expression of Salmonella enteritidis cells adapted to lactic acid and trisodium phosphate and their resistance to lethal heat and acid stress. International Journal of Food Microbiology, 191, 24-31. https://doi.org/10.1016/ j.ijfoodmicro.2014.08.034

Yousef, A.E. and Courtney, P.D. (2003). Basics of stress adaptation and implications in new-generation foods. In Yousef, A.E. and Juneja, V.K. (Eds.) Microbial Stress Adaptation and Food Safety. $1^{\text {st }}$ ed., p. 1-30. Boca Raton, USA: CRC Press.

Zeng, B., Zhao, G., Cao, X., Yang, Z., Wang, C. and Hou, L. (2013). Formation and resuscitation of viable but nonculturable Salmonella typhi. BioMed Research International, 2013, 907170. https:// doi.org/10.1155/2013/907170

Zhu, S., Schnell, S. and Fischer, M. (2013). Growth inhibition of Cronobacter spp. strains in reconstituted powdered infant formula acidified with organic acids supported by natural stomach acidity. Food Microbiology, 35, 121-128. http:// doi.org/10.1016/j.fm.2013.03.005 